\title{
„Dziecko w skorupie”. Ograniczenia w nabywaniu mowy i języka przez jednostki z zaburzeniami ze spektrum autyzmu
}

\section{Streszczenie}

Mowa jako dźwiękowe porozumiewanie się odbywa się dzięki znajomości języka. Nie we wszystkich przypadkach opanowanie mowy przebiega w sposób płynny i bezproblemowy. Odstępstwo od prawidłowego jej rozwoju stanowią przypadki dzieci przejawiających zaburzenia rozwoju mowy i języka, a wśród nich znaczącą grupą są jednostki obarczone cechami ze spektrum zaburzeń autystycznych. Nieumiejętność wykorzystania mowy do komunikowania się jest charakterystyczna dla tej grupy dzieci. Artykuł prezentuje ograniczenia w nabywaniu mowy i języka u dzieci z autyzmem oraz sposoby otwierania ich na świat dzięki rozwojowi komunikacji.

Slowa kluczowe: język, mowa, autyzm, zaburzenia rozwoju mowy i języka

\section{Wprowadzenie}

Człowiek dzięki mowie zyskuje możliwość porozumiewania się z innymi, przekazywania swoich potrzeb, życzeń oraz opisywania emocji. Mowa jako dźwiękowe porozumiewanie się ludzi odbywa się dzięki znajomości języka, stanowiącego system wyrazów oraz reguł gramatycznych. Zdaniem Stanisława Grabiasa mowa to zespół czynności, jakie z udziałem języka wykonuje jednostka, która poznaje rzeczywistość i przekazuje jej interpretację innym członkom grupy społecznej. Tak rozumiana mowa dotyczy trzech rodzajów zachowań: czynności poznawczych człowieka (dokonywanych wyłącznie za pomocą języka, czego efektem jest zorganizowana przy pomocy pojęć wiedza), językowych czynności 
komunikacyjnych (ujawniających się łącznie z zachowaniami mimicznymi i gestowymi), czynności socjalizacyjnych i grupotwórczych (poprzez poznawanie rzeczywistości i porozumiewanie się z innymi jednostkami osoba podlega socjalizacji, zdobywając jednocześnie wiedzę o grupie, której jest członkiem) (Grabias, 1997: 10).

Do porozumiewania się nie wystarczy tylko znajomość języka, konieczne jest także opanowanie umiejętności mówienia oraz rozumienia. Na tym tle rysuje się pojęcie komunikacji identyfikowane z porozumiewaniem się i używane do określenia różnych form działalności ludzkiej, służącej wymianie informacji z użyciem języka jako narzędzia (Kurcz, 2000: 39). Nie we wszystkich przypadkach opanowanie mowy przebiega w sposób płynny i bezproblemowy. Odstępstwo od prawidłowego jej rozwoju stanowią przypadki dzieci przejawiających zaburzenia rozwoju mowy i języka, tj. ,,rozmaite (pierwotne lub wtórne) zaburzenia zachowania językowego w okresie kształtowania i rozwoju mowy (czyli występujące do 6.-7. roku życia), o różnej etiologii” (Jastrzębowska, 2001: 279). Dotyczy to dzieci, które pozbawione są wrodzonej dyspozycji do nauczenia się języka oraz jego realizacji w formie mowy. Wśród nich znaczącą grupę stanowią jednostki obarczone cechami ze spektrum zaburzeń autystycznych. Celem artykułu jest przedstawienie ograniczeń w nabywaniu mowy i języka u dzieci ze spektrum autyzmu oraz sposobów otwierania ich na świat dzięki rozwojowi komunikacji.

\section{„Dzieci w bańce”, czyli o autyzmie słów kilka}

Autyzm to całościowe zaburzenie rozwoju, przejawiające się specyficznym funkcjonowaniem jednostek nim obarczonych. Najistotniejsze są zaburzenia komunikacji oraz trudności w relacjach społecznych. Leo Kanner opisywał autyzm jako „wyraźnie zaburzony rozwój społeczny i rozwój komunikacji w kilku pierwszych latach życia oraz charakterystyczny brak płynności, wyobraźni i udawania w zabawie" (Młynarska, 2008: 89). Wśród specyficznych cech opisywanego zaburzenia należy wymienić przede wszystkim opóźnienie lub niedokształcenie rozwoju mowy oraz rozwoju językowego, brak kontaktów z najbliższym otoczeniem i zamykanie się we własnym świecie oraz niezdolność do nawiązywania kontaktów o charakterze interpersonalnym (Zabłocki, 2002: 29). Stąd w odniesieniu do tej grupy dzieci stosuje się metaforyczne określenia w postaci: dzieci $w$ skorupie, dzieci w bańce. Wszystkie one wskazują na samotność, izolację i brak kontaktów dziecka autystycznego z otoczeniem oraz nawiązują do pochodzenia samego terminu autyzm ${ }^{1}$. Termin autyzm (z gr. autos - 'sam') wprowadził psychiatra Eugen Bleuler, który jednocześnie zdefiniował to zaburzenie jako ,zamknięcie się we własnym świecie i rozluźnienie dyscypliny logicznego myślenia. Oznacza utratę kontaktu z otoczeniem, zamknięcie się w sobie i skierowanie uwagi do wewnątrz" (Bobkowicz-Lewartowska, 2005: 11). Nieumiejętność wykorzystania mowy do komunikowania się jest charakterystyczna dla tej grupy dzieci. Współcześnie, od 2013 roku, zgodnie z wytycznymi DSM-V²

\footnotetext{
1 Wskazane cechy dzieci autystycznych to pewne uproszczenia. Prawidłowe jest indywidualne podejście wobec konkretnej jednostki z autyzmem, która prezentuje inny zakres zaburzeń oraz ograniczeń.

${ }^{2}$ DSM-V - Diagnostic and Statistical Manual of Mental Disorders. Fifth Edition, 2013.
} 
wprowadzono określenie spektrum zaburzeń autystycznych (ASD) w miejsce terminu całościowe zaburzenia rozwoju $u^{3}$.

\section{„Pancerz”, czyli o ograniczeniach w nabywaniu mowy i języka u dzieci z autyzmem}

U dzieci ze spektrum autyzmu dostrzega się jakościowe zaburzenia komunikacji werbalnej i niewerbalnej. Ma miejsce opóźnienie przyswajania języka i opanowywania mowy. Dzieci autystyczne ignorują obecność innych ludzi i nie wykazują zainteresowania nimi. Natomiast dla właściwego rozwoju mowy jest konieczna druga osoba, wobec której realizowane są życzenia, rozkazy czy stawiane pytania.

Zaburzenia umiejętności nawiązywania kontaktu językowego wynikają z występowania jakościowych zaburzeń interakcji społecznych (Frith, 2004: 41). Dysfunkcje w zakresie zdolności społecznych widoczne są u tej grupy dzieci niezwykle wcześnie. Już w pierwszych miesiącach życia można dostrzec wyjątkową wrażliwość na bodźce społeczne. Dzieci te bronią się przed kontaktem fizycznym nawet $\mathrm{z}$ matką, nie utrzymują kontaktu wzrokowego z nikim z otoczenia. Nie wykazują potrzeby okazywania ciepła, uczuć i bliskości. Człowiek dla takich dzieci to jakby kolejny element nieożywionej rzeczywistości, która go otacza. Dzieci z zaburzeniami ze spektrum autyzmu, spotykając na swojej drodze osobę, przesuwają ją albo omijają jak przeszkodę. W niektórych przypadkach korzystają z pomocy osoby, nawet obcej, gdy chcą dotrzeć do interesującej ich rzeczy. Nie jest to jednak prośba kierowana w sposób werbalny (poprzez słowo) bądź niewerbalny (poprzez gest), lecz instrumentalne potraktowanie dorosłego w celu ,oswojenia” obcego przedmiotu. Dlatego dzieci autystyczne często, chwytając dłoń dorosłego, dotykają nią nowych przedmiotów, otwierają drzwi lub sięgają po zabawkę.

Dzieci z ASD na skutek splotu zaburzeń w płaszczyźnie interakcji społecznych, w aspekcie komunikacyjnym oraz ograniczeń w zakresie aktywności i zainteresowań nie są w stanie nauczyć się języka w sposób wystarczający. Przyswajanie języka oraz mowy ma miejsce podczas nieustannego kontaktu dziecka z otoczeniem, z matką. Ważny jest tutaj element naśladowania osoby znaczącej (tj. najczęściej matki) przez dziecko. W przypadku dzieci z autyzmem matka jest traktowana jako element otoczenia i nie podlega obserwacji, a tym samym naśladowaniu 4 . W tym momencie widać, iż koło się zatacza w tym skomplikowanym procesie, jakim jest przyswajanie języka i kształtowanie się mowy u dzieci autystycznych. Dziecko autystyczne nie może nauczyć się mowy, gdyż z powodu autyzmu pozbawione jest w znaczącym stopniu kontaktów społecznych. Poza tym mowa jest czynnością, która wiąże się nie tylko z budowaniem ( $\mathrm{tj}$. nadawaniem), ale także z odbiorem ( $\mathrm{tj}$. rozumieniem) komunikatów werbalnych. Obydwie umiejętności

3 Jednostka ASD (z ang. Autism Spectrum Disorder) zastąpiła trzy jednostki chorobowe: zaburzenia autystyczne, zespół Aspergera i PDD-NOS (całościowe zaburzenie rozwoju niediagnozowane inaczej) (Möller, 2018: 612-616).

${ }^{4}$ Wcześniej istniała teoria tak zwanych zimnych matek, które niesłusznie obarczano odpowiedzialnością za występowanie zaburzeń autystycznych u dzieci. 
nabywane są w trakcie licznych, systematycznych i powtarzalnych sytuacji dnia codziennego. Oto przykład ilustrujący zaburzenia rozumienia poleceń słownych wydawanych czteroletniemu Wiktorkowi z autyzmem (W) przez matkę (M):

M: podaj czapkę (matka zwraca się do chłopca w gabinecie logopedycznym)

$\mathrm{W}$ : ... (chłopiec wykonuje obroty na palcach i nie reaguje na polecenie matki)

M: daj czapkę (powtarza matka)

$\mathrm{W}$ : ... (brak reakcji, chłopiec kontynuuje swoją zabawę)

M: daj czapkę, mówię (matka chwyta dziecko za rękę i wkłada do niej czapkę)5.

Dzieci autystyczne pozbawione zostają możliwości stymulacji ze strony otoczenia. Ze względu na pancerz, w jakim tkwią i którym odgradzają się od otaczającego świata, pozostają zamknięte na wszelkie formy porozumiewania się słownego. Mowa otoczenia jest dla nich tylko pustymi bodźcami o charakterze słuchowym, które dziecko ignoruje lub wręcz ich unika ${ }^{6}$. Jak wiadomo, czynności mówienia towarzyszą liczne zachowania o charakterze niejęzykowym, które dopełniają treść wypowiedzi dodatkowymi informacjami dotyczącymi uczuć i emocji nadawcy. Dzieci z autyzmem w wyniku zaburzeń interakcji społecznych nie nawiązują kontaktu wzrokowego z innymi osobami. Nie uczą się odczytywać emocji z wyrazu twarzy, a tym samym z mimiki. Podobnie słabo posługują się gestykulacją i nie dostrzegają sygnałów przekazywanych przez otoczenie tą drogą ${ }^{7}$. Zakłócenia w odbiorze tych wszystkich zachowań niejęzykowych potęgują trudności w opanowaniu mowy. Brak relacji osobistych z matką oraz innymi bliskimi osobami z otoczenia nie budzi potrzeby nawiązywania kontaktu słownego.

Wśród czynników stymulujących rozwój mowy istotne są także relacje najmłodszych $\mathrm{z}$ rówieśnikami. Nie bez przyczyny zaleca się uczestniczenie dzieci w zajęciach przedszkolnych, wskazując jako zaletę rozwój funkcji poznawczych oraz językowych poprzez kontakty z rówieśnikami i wspólne uczestniczenie w zabawach. Podobnie jak powyżej tak i w kwestii interakcji z rówieśnikami dzieci autystyczne wykazują znaczne ograniczenia. Specyficzną cechą ich funkcjonowania jest brak zainteresowania rówieśnikami oraz podejmowania z nimi jakiejkolwiek aktywności (Piskula, 2005: 65). W wyniku takiej sytuacji i ten sposób nabywania języka zostaje zablokowany. Oto przykład próby nawiązania kontaktu pięcioletniego Michałka (M) z autystycznym kolegą - Grzesiem (G):

M: Daj mi to niebieskie, mate auto.

G: ... (nie zwraca uwagi na słowa kolegi i wkłada wszystkie auta do pudełka, ustawiając je w szeregu)

M: Masz dużo. Daj mi jedno (próbuje nadal Michałek).

G: ... (Grześ milczy i przesuwa kolegę, by sięgnąć po kolejny samochód) ${ }^{8}$.

${ }^{5}$ Kręcenie się wokół własnej osi, chodzenie na palcach należą do stereotypii ruchowych dzieci autystycznych, które dodatkowo preferują aktywność opartą na powtarzalności (Pisula, 2005: 60).

${ }^{6} \mathrm{~W}$ grupie dzieci z zaburzeniami ze spektrum autyzmu niektóre wykazują nadwrażliwość słuchową, która wiąże się z unikaniem wszelkich dźwięków z otoczenia.

${ }^{7}$ Dla osób ze spektrum autyzmu wszystkie interakcje międzyludzkie są trudne ze względu na brak znajomości związanego z mową ciała kodu proksemicznego (Senderska, 2020: 120).

${ }^{8}$ Zachowania Grzesia z autyzmem wskazują na charakterystyczne symptomy tego zaburzenia, tj.: zachowania naruszające cielesność innych oraz traktowanie ich jak przedmiotów (przesuwanie kolegi), brak rozumienia poleceń 
Dzieci niedotknięte autyzmem uczą się zachowań językowych od dorosłych, ale i od rówieśników. Ta ostatnia grupa ma na ich język ogromny wpływ. Dotyczy to zarówno dzieci w wieku przedszkolnym, jak i starszych. Potrzeba uczestniczenia w zabawie pociąga za sobą konieczność nawiązywania relacji społecznych i werbalnych z innymi. Jest to element silnie stymulujący rozwój mowy dzieci. Uczestniczenie w zabawach, głównie tematycznych, takich jak: „w dom”, „w lekarza”, „w sklep”, służy rozwijaniu kompetencji językowych, ale także sprawności sytuacyjnej i pragmatycznej (Grzesiak-Witek, 2006: 103-105). Dzieci autystyczne, nie wchodząc w relacje z rówieśnikami, nie biorą udziału w zabawach, a tym samym nie czerpią z nich żadnych korzyści.

\section{„Otworzyć się na świat”. O sposobach rozwijania komunikacji dzieci $z$ autyzmem}

Język dla dziecka, jak i dla każdego człowieka staje się perspektywą patrzenia na świat, sposobu jego odbierania oraz wartościowania elementów go stanowiących. Istotnym elementem tej rzeczywistości są ludzie oraz samo dziecko jako nadawca danej wypowiedzi. „Nabywając symbole językowe dla danej kultury, dziecko uczy się z różnych perspektyw oglądać te same osoby, przedmioty i zdarzenia. Nazwy dokonują kategoryzacji, uwalniają poznawanie od bezpośredniej percepcji, pozwalają orzekać o tym, co nie jest obecne w polu widzenia" (Cieszyńska-Rożek, 2013: 103). Pracując nad otwarciem dziecka autystycznego na świat, należy zadbać o opanowanie przez nie języka oraz mowy.

$\mathrm{Na}$ początek istotne jest ukazanie dziecku autystycznemu korzyści płynących z posługiwania się mową. Cel ten można osiągnąć, skupiając się nad językową sprawnością pragmatyczną, czyli umiejętnością „osiągania celu założonego przez nadawcę wypowiedzi” (Jastrzębowska, Pelc-Pękala, 2001: 648). Małe dziecko autystyczne, które odkryje moc słowa daj, będzie wiedziało, że poprzez mowę może wpływać na otoczenie. Dzięki mowie dostanie przedmiot (zabawkę), jaka wcześniej pozostawała poza jego zasięgiem. Jednocześnie ważne pozostaje stworzenie wspólnego pola uwagi dziecka i osoby z najbliższego otoczenia (matki bądź terapeuty mowy) ${ }^{9}$. Stanowi to podstawę do wszelkich działań stymulujących rozwój mowy, jak i fundament skutecznej komunikacji.

Formę rutynowego zachowania dzieci autystycznych (powyżej 3. roku życia) stanowią zadawane przez nie pytania bez oczekiwania na uzyskanie odpowiedzi. Terapeuta mowy powinien zadbać o to, by włączyć dziecko do aktywności w najbliższym otoczeniu poprzez kierowanie pytań istotnych dla niego samego. Uzyskuje się to dzięki wprowadzaniu zdań pytających na tematy zgodne z zainteresowaniami dziecka z autyzmem. Wiadomo, że zakres tych zainteresowań jest w tej grupie zawężony i specyficzny, dlatego by nawiązać

oraz nieumiejętność wykorzystania zabawek zgodnie z ich przeznaczeniem (chłopiec układa autka w szereg). Zob. Grzesiak-Witek, 2013: 60-65.

${ }^{9}$ Brak wspólnego pola uwagi jest jednym z głównych objawów zaburzeń komunikacji u dzieci z autyzmem, który uniemożliwia skuteczną terapię (Pisula, 2005: 70). 
z dzieckiem relację, terapeuta musi wejść w jego świat ${ }^{10}$. Może to uzyskać, uczestnicząc w zabawie z dzieckiem jego ulubionymi zabawkami czy formułując pytania dotyczące interesujących dziecko kwestii. Podczas terapii należy w pewien sposób podążać za dzieckiem, rozpoczynając stymulację od umiejętności, którą już dziecko posiada. Ma miejsce łagodne, choć poprzedzone licznymi ćwiczeniami, przechodzenie do zachowań mieszczących się w normie, a dotyczących zachowań językowych i społecznych (Cieszyńska-Rożek, 2008: 102).

Otwieranie się na świat w przypadku dziecka z autyzmem wiąże się z dążeniem do osiągnięcia przez nie poziomu rozwoju zgodnie z normami adekwatnymi dla wieku. Strategie zastosowane podczas całej terapii polegają na łączeniu ćwiczeń motoryki małej i praksji oralnej z nauką umiejętności skupiania uwagi na twarzy terapeuty i materiale zadaniowym. Przez cały czas konieczna jest również regulacja zachowań uzyskiwana dzięki uczeniu językowych reguł społecznych i nazywaniu emocji - tych przeżywanych, ale i obserwowanych $\mathrm{u}$ innych. Znaczące miejsce w terapii dzieci autystycznych w ujęciu Jagody Cieszyńskiej-Rożek zajmuje wczesna nauka czytania, która umożliwia ćwiczenie funkcji językowych, a także wpływa na stymulację określonych struktur mózgowych (Cieszyńska-Rożek, 2008: 114).

Każde zachowanie językowe wypracowane w gabinecie przez terapeutę mowy wymaga utrwalania w środowisku dziecka. Odpowiedzialnymi za ten fakt czyni się rodziców i (w miarę możliwości) nauczycieli w przedszkolu/szkole. Podczas posiłków, spacerów, wspólnych zabaw pojawia się wiele sytuacji, w jakich można zastosować wyćwiczone w sztucznych warunkach gabinetowych zachowania językowe i społeczne. Dom, miejsce zabaw są miejscami, w jakich pojawia się wiele okazji do utrwalania interakcji językowych. W przypadku środowiska rodzinnego sam czas posiłków przynosi możliwość nazywania czynności związanych z siedzeniem, jedzeniem, piciem oraz przywoływania określeń poszczególnych potraw i kolorów, w jakich występują. To tylko niektóre z przykładów utrwalających leksykę i aktualizujących nazwy przedmiotów, czynności i cech.

\section{Podsumowanie}

Prawidłowy rozwój mowy, opanowanie języka oraz właściwe komunikowanie się z otoczeniem stanowi podstawę funkcjonowania w otaczającej rzeczywistości. Jednocześnie wpływa na kształtowanie się osobowości danej jednostki, jej samoocenę, jak i ocenę innych dotyczącą tej osoby. Umiejętność mówienia pozwala wyrazić i opisać swoje uczucia oraz poglądy, natomiast rozumienie umożliwia odbiór informacji i poszerzenie horyzontów na temat otaczającego świata. Praca z jednostkami z zaburzeniami ze spektrum autyzmu należy do trudnej i obciążającej emocjonalnie ze względu na specyfikę zaburzenia i współwystępowanie deficytów komunikacyjnych i społecznych. Niemniej

${ }^{10}$ Dzieci autystyczne zafascynowane są zabawkami lub przedmiotami, które na przykład świecą, kręcą się lub wydają dźwięki (Zabłocki, 2002: 61). 
jednak ze względu na szczytny cel, jakim jest otwarcie tych osób na otaczający świat i ludzi, warto podjąć się tego zadania.

\section{Bibliografia}

Ball J. (2016), Autyzm a wczesna interwencja: rzeczowe pytania, życiowe odpowiedzi, Gdańsk. Bobkowicz-Lewartowska L. (2005), Autyzm dziecięcy, zagadnienia diagnozy i terapii, Kraków. Cieszyńska-Rożek J. (2008), Standard postępowania logopedycznego w przypadku autyzmu wczesnodziecięcego, „Logopedia”, nr 37.

Cieszyńska-Rożek J. (2013), Metoda Krakowska wobec zaburzeń rozwoju dzieci, Kraków.

Frith U. (2004), Autyzm. Wyjaśnienie tajemnicy, Gdańsk.

Grabias S. (1997), Mowa i jej zaburzenia, „Audiofonologia”, nr 10.

Grandin T., Panek R. (2016), Mózg autystyczny: podróż w głąb niezwykłych umysłów, Kraków.

Grzesiak-Witek D. (2006), Petnienie ról rodzinnych $w$ zabawie tematycznej dzieci w wieku przedszkolnym, „Społeczeństwo i Rodzina”, nr 9.

Grzesiak-Witek D. (2013), Program terapii logopedycznej dziecka z autyzmem w oparciu o studium indywidualnego przypadku, „Społeczeństwo i Rodzina”, nr 37.

Hickok G. (2016), Mit neuronów lustrzanych. Rzetelna neuronauka komunikacji i poznania, Kraków.

Jastrzębowska G. (2001), Zaburzenia komunikacji językowej (wyjaśnienie podstawowych pojęć), [w:] T. Gałkowski, G. Jastrzębowska, Logopedia. Pytania i odpowiedzi, Opole.

Jastrzębowska G., Pelc-Pękala O. (2001), Metodyka ogólna diagnozy i terapii logopedycznej, [w:] T. Gałkowski, G. Jastrzębowska, Logopedia. Pytania i odpowiedzi, Opole.

Kurcz I. (2000), Psychologia języka i komunikacji, Warszawa.

Młynarska M. (2008), Autyzm w ujęciu psycholingwistycznym: terapia dyskursywna a teoria umystu, Wrocław.

Möller H.-J. (2018), Możliwości i ograniczenia DSM-5 w polepszeniu klasyfikacji i diagnozy zaburzeń psychicznych, „Psychiatria Polska”, nr 52(4).

Pisula E. (2005), Małe dziecko z autyzmem, Gdańsk.

Senderska J. (2020), Obraz osoby z zaburzeniem ze spektrum autyzmu w literaturze popularnej (na przykładzie bohatera powieści Jodi Picoult „, W naszym domu”), „Respectus Philologicus”, nr 37(42).

Silbermani S. (2017), Neuroplemiona: dziedzictwo autyzmu i przyszłość neuroróżnorodności, Białystok.

Zabłocki K. (2002), Autyzm, Płock. 


\section{Abstract \\ "Child in a shell". Limitations in the speech and language acquisition of children with autism spectrum disorders}

Speech as audible communication is achieved due to the knowledge of a language. Speech acquisition does not always proceed smoothly and without any problems. Deviation from the proper development of speech is seen in the case of children with disorders of the development of speech and language, among whom children with characteristic autism spectrum disorders constitute a considerable group. The inability of using speech for communication is characteristic of this group of children. The article presents limitations in acquiring speech and language by children with autism as well as ways of opening them up to the world through the development of communication.

Keywords: language, autism, speech and language development disorders 